\title{
The Effect of Exercise Therapy on Pain in Mothers After Sectio Caesarea
}

\author{
Nungki Marlian Yuliadarwati \\ Department of Physiotherapy, Faculty of Health Science, University of Muhammadiyah Malang, \\ Indonesia \\ Jl. Bendungan Sutami 188A, Kota Malang, Jawa Timur, 65145 \\ Corresponding author: nungki.fisio2@gmail.com
}

\begin{abstract}
Background: Sectio caesarea is the last option for saving the lives of mother and foetus if vaginal delivery faces obstacles. Sectio caesarea action may result in complications of pain that is felt due to tissue damage. Post-caesarian section pain is accute in nature and requires immediate treatment as it may cause restriction in the everyday activities and disturb the recovery process. Objective: This research was intended to find out the effect of exercise therapy on pain intensity in mothers after sectio caesarea. Method: This researchused quasi-experiment method with pre-and post-test control group design. The samples of this research were divided into two, one of which was a treatment group with exercise therapy treatment that consisted of 25 samples, and another one was a control group with early mobilization that consisted of 25 samples. The pain intensity was measured using VAS (Visual Analog Scale). Result: Test of pain intensity in two groups of mothers after sectio caesarea, there was a difference with a value $p=0.009(p=<0.05)$. Conclusion: It was concluded that exercise therapy can reduce the pain intensity in mothers after sectio caesarea.
\end{abstract}

Keywords: post-caesarean section, exercise therapy, pain intensity

\section{INTRODUCTION}

Section caesarea is a method for saving mother and foetus if it is not possible to do normal delivery. Sectio caesarea has a lot of complaits such as pain around the incision aea, infection, bleeding, uterine rupture, alergy and breast milk production disturbance (Kasdu, 2003). The side effect of sectio caesarea action is pain in the incision area, which may cause disruption to the mother's daily activities after section caesarea. A state hospital in Surabaya states that the incidence rate of caesarean section increases by $22.28 \%$ per year. According to WHO data in 2013, the incidence rate of caesarean section in Thailand increased to $32 \%$ from $21 \%$. Judging from the increase in the rate of birth by c-section, Physiotherapy offers a number of exercise therapy methods to reduce pain around incision area, one of which is using osteopathic technique, which manipulates the soft tissues by engaging direct movements with movement control by the patient him-/herself during isotonic or isometric contraction to improve the musculoskeletal function and reduce pain (Chaitow, 2006). Light movements during postpartum period aim at reducing the pain intensity, incresing the tone of muscles, and maintain and improve blood circulation of mothers (Brayshaw, 2008).

This research aimed to figure out the effect of exercise therapy on pain intensity in mothers after sectio caesarea. 


\section{METHOD}

The method used in this research was quasi-experiment with pre- and post-test control group design. The independent variable of this research was exercise therapy. Meanwhile, the dependent variables consisted of pain intensity and daily activities. The control variables consisted of age, drug use and the first c-section birth. The research was conducted on 50 subjects, with the use of calculation formula by Rosner, 2012. The subjects were taken from some maternity hospitals in Surabaya who met the inclusion criteria, where the mothers should have been 20-35 years old and had just undergone their first c-section. The samples were devided into two groups, which consisted of a treatment group with a treatment of exercise therapy, and control group with early mobilization. The pain intensity is measured before and after intervention using VAS.

A statistical analysis in the normality test was used for figuring out whether the samples used in the research were from the same population or whether the data used in the research was normally distributed or not. This analysis used Shapiro-Wilk test using SPSS program (Purwanto and Irwandi, 2014).

Discrimination test was conducted in a group and between groups. When the normality test yielded normally distributed data, the discrimination test between groups used a parametric test, namely independent sample t-test. However, when the normality test yielded results that were not normally distributed, the discrimination beteen groups used non-parametric test, namely Mann Whitney test (Purwanto and Irwadi, 2014).

\section{RESULT AND DISCUSSION}

The samples of this research was taken from the post-caesarean section inpatients in a number of maternity hospitals. The samples consisted of 50 people at the age of 20 to 35 , who had just given birth for the first time and did not have any complication. The exercise therapy was carried out once every two hours with 8 counts and 5-10 repetitions for four days during the treatment in the hospital.

The number of samples was 50, which was devided into two groups. The data of the samples was identified based on the age of the mothers when giving birth, body temperature, respiration and cause of c-section.

Before doing exercise therapy, measurement of pain intensity using VAS was conducted on both treatment and control groups. It was found out that the pain intensity in mothers after c-section decreased.

Table 1 Results of descriptive analysis on the research subject distribution based on age (years old), body temperature $\left({ }^{\circ}\right)$ and respiration $(\mathrm{X} / \mathrm{minute})$.

\begin{tabular}{llll}
\hline No. & Characteristics of Subject & N & Mean \pm SD \\
\hline 1 & Age & 50 & $27 \pm 2.105$ years old \\
2 & Body Temperature & 50 & $37 \pm 0.768^{\circ} \mathrm{C}$ \\
3 & Respiration & 50 & $22 \pm 0.916$ times/minute \\
\hline
\end{tabular}

Based on the background of the research aiming to prove the effect of the application of exercise therapy on the pain intensity in mothers after c-section at the age of 20-30, the research conducted was experimental research with quasi-experimental method. The research design used was pre-test post-test control group design. The number of subjects of this research was calculated using Rosner's formula. According to the calculation, the number of the subjects obtained, with an addition of $10 \%$ as the correction 
factor in the number of samples, was 25 for each group. The total number of samples in this research was 50 .

Table 2 Results of c-section subject frequecy distribution by cause

\begin{tabular}{llll}
\hline & & Group Frequency & \\
\cline { 3 - 4 } No. & C-Section Causes & Exercise Therapy & Control \\
\hline 1 & Transverse Lie & 4 & 3 \\
2 & Narrow Pelvis & 3 & 5 \\
3 & Placenta Previa & 5 & 3 \\
4 & Preeclapsia & 5 & 5 \\
5 & Premature Rupture of the Membrane & 2 & 5 \\
6 & Twins & 1 & 1 \\
7 & Big Baby & 2 & 2 \\
8 & Fetal Distress & 3 & 1 \\
\hline TOTAL & 25 & 25 \\
\hline
\end{tabular}

Table 3 Results of normality test of pre- and post-test data of pain intensity

\begin{tabular}{llll}
\hline No. & Variables & $\mathrm{N}$ & Significance $(\mathrm{p})$ \\
\hline 1 & Value of pain pra exercise therapy $(\mathrm{cm})$ & 25 & $0.009 *$ \\
2 & Value of pain post exercise therapy $(\mathrm{cm})$ & 25 & $0.009 *$ \\
3 & Value of pain pra control group $(\mathrm{cm})$ & 25 & 0.089 \\
4 & Value of pain pot control group $(\mathrm{cm})$ & 25 & 0.080 \\
\hline \multicolumn{4}{l}{ Note: } \\
\multicolumn{5}{l}{ Saphiro (before exercise therapy treatment), post (after exercise therapy treatment), $\mathrm{p}$ (normality test with } \\
\multicolumn{5}{l}{ Source: Primary Data }
\end{tabular}

Table 4 Results of homogeneity test: average pain intensity in mothers after c-section

\begin{tabular}{llll}
\hline No. & Variables & Mean \pm SD & $\mathrm{P}$ \\
\hline & Mean of value of pain pra exercise therapy & & \\
1 & - Mean of value of pain pra control & $-7.596 \pm 21.581$ & 0.085
\end{tabular}

Table. 5 Results of analysis of difference in pain intensity of exercise therapy group and control group

\begin{tabular}{ll}
\hline Variable & Significance $(\mathrm{p})$ \\
\hline $\begin{array}{l}\text { Difference of values of pain intensity before and } \\
\text { after exercise therapy treatment }\end{array}$ & \\
\hline
\end{tabular}

Note $: \mathrm{p}>0.05$. Source: Primary Data

The decrease in the pain intensity resulted from the exercise therapy shows insignificant difference with value $p=0.009(p<0.05)$. The results of the discrimination test of the pain intensity of exercise therapy group and control group in mothers after csection proved that there is a difference between exercise therapy and early mobilization. This proved that the exercise therapy carried out once every 2 hours with 8 counts and 3-5 repetitions during the hospitalization can reduce the pain intensity in mothers after csection. This is due to the fact that exercise therapy heavily involves the movements of the upper limbs such as the shoulders, arms, wirsts, and lower limbs such as the hips, abdomen and back as the stimulation/trigger for the epinephrine, growth hormone and endorphine.

Exercise therapy in mothers in the postpartum period helps recover the uterus, strenghten the abdominal muscles, balance the back muscles and hip muscles experiencing trauma, and return those body parts, especially the uterus, into their normal shapes (Gallagher, 2006). Carpenito (2009) explains that an active movement in the form of 
exercise therapy is the most important aspect of physiological functions that aims to maintain and balance the strength of the abdominal and back muscles. Therefore, exercise therapy can maintain the physiological functions to maintain and improve independence as early as possible and prevent any complication.

According to the theory, exercise therapy affects the epinephrine by activating receptor $\alpha$ and $\beta$, including improving glicolysis, relaxation of the smooth muscles of the veins, lipolysis stimulation, myocardium contraction, blood circulation and muscle glicolysis, that improve the muscle strength, improving the blood circulation and inhibiting tissue damage (Guyton, 2006).

The growth hormone is supported by cytokine in the inflammation process during the c-section to prevent further coagulation and to break the fibrine clot to ease the cell migration to the wound area and start the next recovery phase (Guyton, 2006). Based on the theory, endorphine works as a natural sedative which causes the sense of comfort. The increased endhorphine level in the body can reduce pain during contraction. Exercise therapy can increase the endorphine level in the blood four- to fivefold. Thus, the more exercise therapy is done, the higher the endorphine level is. The endorphine increase is proved to have a close relationship with the dicrease in pain, increase in memory, better appetite, better sexual ability and better blood pressure and respiration, showing that exercise therapy is effective for reducing pain (Guyton, 2006).

The results of the research on exercise therapy combined with breathig exercise on the reduction of pain intensity in patients after abdominal operation at Karima Utama Hospital, Surakarta, in 2006 by Dianingsih show that there is a significant effect. Breathing exercise can control pain in the body. This will improve the parasimpatic nerve components simultaneously. As a result, the adrenaline and cortisol that cause stress will be reduced and the person will experience increased consentration and sense of calmness (Handerson, 2010).

\section{CONCLUSION}

Based on the resesarch results and the discussion on the effect of exercise therapy in decreasing the pain intensity in mothers after c-section, the value obtained was $\mathrm{p}=$ 0.009 ( $p<0.05)$. For resarch sharing the same topic with this research, it is suggested that the research include the examination of abdominal and back muscle strength as the main exercise in the exercise therapy.

\section{REFERENCES}

Brayshaw, E. (2008). Senam Hamil dan Senam Nifas, Jakarta: EGC

Carpenito, L.J. (2009). Diagnosis keperawatan, Aplikasi Pada Praktek Klinis (9th Ed). Jakarta: EGC

Chaitow, L. (2000). Muscle Energy Technique (3rd Ed). Churchill Livingstone: Edinburgh. Gallagher C. M. (2006). Pemulihan pasca operasi caesar. Jakarta: Erlangga.

Guyton, A.C., \& Hall, J.E. (2006). Buku Ajar Fisiologi Kedokteran (11th Ed). Penterjemah: Irawati, Ramadani D, Indriyani F. Jakarta: EGC 